\title{
RACISM AND LEgAL CULTURE: IS THERE ROOM FOR Diversity IN THE LegAL Profession?
}

\author{
JOAN BROCKMAN*
}

\section{INTRODUCTION}

The nutshell summary of these articles is that Charles C. Smith tells us what is wrong with the legal profession and optimistically what can be done to improve diversity, and $\mathrm{W}$. Wesley Pue explains, from an historical perspective, why there may be resistence to diversity. I will use their articles as a springboard to comment on racism and legal culture in the legal profession.

Smith makes the following points in his article:

(1) The legal profession has failed to recognize racism within itself;

(2) There is a lack of information about the racialized composition of the legal profession and judiciary;

(3) There has been an "undramatic increase [or perhaps a decrease] in the numbers of Aboriginal lawyers and lawyers from subordinate racialized groups";

(4) Both law schools and the legal profession are the agents who keep the profession largely white;

(5) There are many examples of what law schools and the legal profession are doing and could be doing to make the legal profession more representative of Canadian society in terms of Aboriginal lawyers and lawyers from racialized groups. ${ }^{2}$

\section{Does the Legal Profession Recognize RaCism?}

Perception is as important as reality. In a survey of Alberta lawyers conducted in 2003, 91 percent of racialized lawyers and 73 percent of Caucasian lawyers thought there was discrimination in the legal profession against lawyers belonging to racial or ethnic minority groups. Only 3.5 percent of racialized lawyers and 14.9 percent of Caucasian lawyers thought there was no discrimination. ${ }^{3}$

Professor, School of Criminology, Simon Fraser University. These are comments on articles by Charles C. Smith and W. Wesley Pue presented to Canadian Lawyers in the 21st Century, 26 October 2007 Edmonton, Alberta. I would like to thank Susan B. Boyd for her helpful comments on an earlier draft. Charles C. Smith, "Who is Afraid of the Big Bad Social Constructionists? Or Shedding Light on the Unpardonable Whiteness of the Canadian Legal Profession" (2008) 45:5 Alta. L. Rev. 55 at 57.

2 See also Susan V.R. Billington's recent summary of the work done by the Law Society of Alberta (LSA) on this issue: Law Society of Alberta, Diversity \& Equality Initiatives: 1991-2006, online: LSA $<$ http://www.lawsocietyalberta.com/files/reports/Equality_Diversity_Initiatives_2006.pdf $>$.

3 Joan Brockman, "An Update on Gender and Diversity Issues in the Legal Profession in Alberta, 19912003" in Elizabeth A. Sheehy \& Sheila McIntyre, eds., Calling for Change: Women, Law, and the Legal Profession (Ottawa: University of Ottawa Press, 2006) 237 at 240 [Brockman, "Update on Gender"]; 
Smith also talks about the impact of socio-economic class on law school admissions, a variable which is often ignored in these discussions. Working-class students no longer have the same educational opportunities that my generation had. An increase in scholarships and bursaries made available to law students will not affect the "sticker shock"4 which will continue to keep many excellent working-class students out of law schools. Their exclusion will of course mean that there will be more room for mediocre middle- and upper-class students.

\section{LACK OF INFORMATION ON WHERE WE ARE AND WHERE WE ARE GOING}

Why are law societies not conducting censuses ${ }^{5}$ of their members in relation to race and ethnicity? No one has ever made the argument that we should increase the number and proportion of women in the legal profession without knowing how many there are and what proportion they represented historically or represent today.

Law societies do report on the gender of their members, although the question only has two answers - male and female. Committees drafting questionnaires have ground to a halt over the issue of how many sexes or genders to include: male, female, transgendered male, transgendered female. Should intersexed individuals be included? What about two-spirited? Is two-spirited a sexual orientation or a third gender? ${ }^{6}$ Despite all of these definitional challenges, law societies still keep track of whether their members are male or female and report these statistics on their websites. ${ }^{7}$ Some law societies do a much better job at such reporting than others. This reporting is a very good start.

One of the arguments against surveying race and ethnic background or social class is that these variables are too difficult to measure. As with gender, there will always be problems with the way we measure these other characteristics. However, whenever possible, surveys

Merrill Cooper, Joan Brockman \& Irene Hoffart, Final Report on Equity and Diversity in Alberta's Legal Profession (Completed for the Joint Committee on Equality, Equity and Diversity) (2004), online: LSA <http://www.lawsocietyalberta.com/files/reports/Equity_and_Diversity.pdf> at 128 [Cooper, Brockman \& Hoffart, Final Report]. See also Fiona M. Kay, Cristi Masuch \& Paula Curry, "Growing Diversity and Emergent Change: Gender and Ethnicity in the Legal Profession" in Sheehy \& McIntyre, ibid. at 203. Racism in the legal profession is also addressed in: Canadian Bar Association, The Challenge of Racial Equality: Putting Principles into Practice (Ottawa: Canadian Bar Association, 1999); Canadian Bar Association, Virtual Justice: Systemic Racism and the Canadian Legal Profession (Ottawa: Canadian Bar Association, 1999) (An Independent Report by Joanne St. Lewis, Co-Chair of the Working Group on Racial Equality in the Legal Profession).

4 Susan B. Boyd, “Corporatism and Legal Education in Canada” (2005) 14 Soc. \& Leg. Stud. 287 at 294; Jo-Anne Pickel, "What Will Rising Law School Tuition Fees Mean for Law and Learning?" (2003) 18 C.J.L.S. 67 at 70.

5 I am using the word census to mean a mandatory reporting by every member of the profession. A survey on the other hand, only gives a snapshot (usually anonymous) of the characteristics of the profession at any given time. Responses to these surveys are not mandatory, and therefore the response rate may distort the reality of the characteristics of members of the law societies.

6 See discussion and links provided: Queen's Postive Space Program, online: Queen's University $<$ http://www.queensu.ca/positivespace/glossary.htm\#5>.

7 Law societies report their statistics on male and female lawyers to the Federation of Law Societies which then posts them on its website: Statistics of Law Societies, online: Federation of Law Societies of Canada $<$ http://www.flsc.ca/en/lawSocieties/statisticsLinks.asp $>$. 
or censuses should use Statistics Canada categories ${ }^{8}$ for a number of reasons. First, using Statistics Canada wording eliminates heated and lengthy debates over how to phrase the question. Second, using Statistics Canada classifications provides an explanation to lawyers who are responding to the questionnaire or census as to why the questions are being asked. Third, this explanation may increase the response rate to the questions. ${ }^{9}$ In the 2003 survey of Alberta lawyers, we replicated four questions from Statistics Canada Census on race, language learned at home, language spoken at home, and religion. The questions were introduced with the following comment: "Please note: Questions 40 to 43 were replicated from the most recent Statistics Canada Census and are included here to allow for comparison with census data." questions should not appear novel or unusual.

According to The Lawyers Weekly, the Nova Scotia Barristers' Society now asks its members about sexual orientation on its mandatory annual member report, ${ }^{11}$ however, the form on the website has not been updated so I could not find how the question is asked. ${ }^{12}$ The Executive Director is quoted as explaining the need for such a question: "Only when we better understand the profile of the profession can we design programs to support lawyers and address issues unique to groups [...] of lawyers." 13 It will be impossible to determine whether any progress is made on diversity in the legal profession without some sort of measurement. To the extent there is lack of will and resistence to determining diversity facts, progress will be stifled. ${ }^{14}$

\section{THE UNDRAMATIC INCREASE IN DIVERSITY NUMBERS}

Smith also addresses the undramatic increase in the number of Aboriginal lawyers and lawyers from racialized groups. Table 1 (below) shows the percentage of the Ontario population in 2001, compared to characteristics of those who self-identified upon their enrolment in the Bar Admission Course of the Law Society of Upper Canada (LSUC) between 2002 and 2006. These statistics are an excellent start, and the Law Society should be congratulated for gathering and posting them. More information though is needed on what happens to these individuals as they work their way into or out of the legal profession. What number and proportion make it through the Bar Admission course? What number and proportion find articling positions? What number and proportion find a job after their call? What number and proportion are still practising law 5, 10, and 15 years after their call? What are the locations where they choose or are forced to work? Are they fitting in or altering the

See online: Statistics Canada <http://www.statcan.ca/english/concepts/definitions/ethnicity01.htm>. As well, a mandatory census would eliminate the response rate problem that affects voluntary questionnaires.

10 See Cooper, Brockman \& Hoffart, Final Report, supra note 3, Appendix 1 at 9.

1 Donalee Moulton, "NS Barristers' society asks members about sexual orientation" The Lawyers Weekly (28 September 2007) (QL).

12 I requested the wording of the question from the Executive Director, Nova Scotia Barristers' Society by e-mail on 7 November 2007 and am awaiting a response.

13 Moulton, supra note 11 at para. 2.

14 I am not suggesting that definitional problems are the only reasons why such data are not collected. 
legal mould $?^{15}$ There is also the question mentioned above of whether law societies should restrict their data-gathering to people who choose to self-identify. The census requires us to answer questions about ourselves. If law societies want to know how they are doing on the question of diversity, voluntary self-identification is not sufficient.

Table 1

Percentage of the Ontario Population Compared to Characteristics

of Those Who Self-Identified on Their Enrolment to the

Bar Admission Course, Law Society of Upper Canada, 2002-2006 ${ }^{16}$

\begin{tabular}{|l|c|c|c|c|c|c|}
\hline \multicolumn{1}{|c|}{$\%$ Population } & $\mathbf{2 0 0 1}$ & $\mathbf{2 0 0 2}$ & $\mathbf{2 0 0 3}$ & $\mathbf{2 0 0 4}$ & $\mathbf{2 0 0 5}$ & $\mathbf{2 0 0 6}$ \\
\hline Racialized & $19 \%$ & $16.5 \%$ & $18.8 \%$ & $15.8 \%$ & $15 \%$ & $19 \%$ \\
\hline Aboriginal & $1.6 \%$ & $1.7 \%$ & $1.4 \%$ & $1.3 \%$ & $1.5 \%$ & $1.5 \%$ \\
\hline Francophone & $4.3 \%$ & $5.4 \%$ & $5.8 \%$ & $4.5 \%$ & $5 \%$ & $4.3 \%$ \\
\hline Women & $51.2 \%$ & $53 \%$ & $53 \%$ & $54.5 \%$ & $54 \%$ & $55.8 \%$ \\
\hline
\end{tabular}

Even if various groups are admitted in proportion to their representation in the population, there is quite a time lag in terms of seeing any effect. Just a brief look at the entrance of women into the profession in Alberta ${ }^{17}$ shows that between 1986 and 1990, 35 percent of those called to the bar in Alberta were women; however, in 1991 only 20 percent of active members of the Law Society were women. Between 1998 and 2002, 45 percent of those called to the bar in Alberta were women; however in 2003, only 29 percent were women. In 2006, 47 percent of those called in Alberta were women, but only 33 percent of the active members were women. In addition to the time lag, other important factors are in operation: women and members of racialized minority groups are more likely to leave the profession and not become completely integrated into all structures and areas of practice. ${ }^{18}$

15 I address this question on the issue of gender in Joan Brockman, Gender in the Legal Profession: Fitting or Breaking the Mould (Vancouver: University of British Columbia Press, 2001). For an excellent analysis of how the first women lawyers around the world had to become lawyers ungendered (or more likely, male-gendered) because of the entrenched male culture, see Mary Jane Mossman, The First Women Lawyers: A Comparative Study of Gender, Law and the Legal Professions (Portland, Or.: Hart, 2006).

16 These numbers are taken from the Law Society of Upper Canada (LSUC) website, "The Changing Face of the Legal Profession," online: LSUC <http://www.lsuc.on.ca/latest-news/b/fact/changing/>.

17 I chose women lawyers in Alberta because similar statistics for Aboriginals and racialized groups do not exist.

18 Brockman, "Update on Gender," supra note 3 at 237-38; Joan Brockman, "Leaving the Practice of Law: The Wherefores and the Whys" (1994) 32 Alta. L. Rev. 116; Cooper, Brockman \& Hoffart, Final Report, supra note 3 at 19-53; Fiona M. Kay, "Flight from Law: A Competing Risks Model of Departures from Law Firms" (1997) 31 Law \& Soc'y Rev. 301; John Hagan \& Fiona Kay, "Even Lawyers Get the Blues: Gender, Depression, and Job Satisfaction in Legal Practice" (2007) 41 Law \& Soc'y Rev. 51. 


\section{The Role of Legal Culture}

The question of how law schools and the profession perpetuate their whiteness leads into Pue's paper on legal culture. Pue tells us that law societies' historical and continuing professionalization projects are not only about the money (that is, not just about achieving wealth through a state-backed monopoly on legal services), but also a means of transmitting a legal culture, a kind of "lawyers' hegemony," in order to preserve amongst other things, the "Britishness" of the profession. ${ }^{19}$ Pue suggests that the notions of professionalism and the good practitioner contain(ed) elements of class bias and racism. ${ }^{20}$ If, as Pue suggests, legal culture is partly to blame for racism and lack of diversity in the legal profession, how does legal culture operate to stall such diversity? ${ }^{21}$

In order to examine how legal culture might assist practitioners in justifying racism, I have borrowed the concept "techniques of neutralization" from two criminologists who, in the 1950s, explained how juvenile delinquents managed to drift in and out of delinquency and justify their delinquent behaviour. ${ }^{22}$ Techniques of neutralization have since been used to explain how numerous other offenders, including white-collar criminals, justify their behaviour and maintain their non-criminal identities. ${ }^{23}$

Although some techniques of neutralization originate in individual circumstances, for the most part, these techniques originate and are cultivated in the culture of the group. I am suggesting that they originate in and are cultivated through professional legal culture. Just as corporate culture might support corporate crime, ${ }^{24}$ legal culture might support racism -a form of unethical behaviour and a violation of human rights. How do lawyers engage in racism and yet maintain their non-racist identities? Assuming that there are individuals in the legal profession who engage in conscious forms of racism, how do they reconcile these attitudes and behaviour as members of a legal profession which says it is unacceptable?

Techniques of neutralization provide rationalizations, supported by the group, for the inappropriate behaviour. For example, physicians who engage in health care fraud, ${ }^{25}$ and to

W. Wesley Pue. "Cowboy Jurists and the Making of Legal Professionalism" (2008) 45:5 Alta. L. Rev. 29 at 43.

Ibid. at 48.

Racism and its manifestations are obviously much more complicated. However, how lawyers justify racism to themselves and others may be a small piece of the puzzle.

Gresham M. Sykes \& David Matza, "Techniques of Neutralization: A Theory of Delinquency" (1957) 22 American Sociological Review 664.

Joan Brockman, "Fraud Against the Public Purse by Health Care Professionals: The Difference of Location" in Janet Mosher \& Joan Brockman, eds., Creating Crime through Law-in-Action [unpublished] [Brockman, "Fraud"]; James William Coleman, The Criminal Elite: Understanding White-Collar Crime, 5th ed. (New York: Worth, 2002) at 194-99; Paul Jesilow, Henry N. Pontell \& Gilbert Geis, Prescription for Profit: How Doctors Defraud Medicaid (Berkeley: University of California Press, 1993) at 186.

24 See e.g. Harry Glasbeek, Wealth by Stealth: Corporate Crime, Corporate Law, and the Perversion of Democracy (Toronto: Between the Lines, 2002) at 141-42.

Since I have not conducted research on techniques of neutralization in the legal profession, I will provide an example from medicare/OHIP fraud and leave the reader to think about how it might work in the legal profession. In 1994, when I interviewed a random sample of women and men lawyers called between three and seven years, only 23 percent of the women and 38 percent of the men thought that antidiscrimination rules would be effective to reduce discrimination. Although I did not ask them about 
some extent those who monitor health care fraud, will use words like "upcoding" when health care professionals fraudulently charge for a more expensive procedure than the one performed. Other phrases such as "over-billing," "aggressive billing," "inappropriate billing," "fudging," and "padding" leave the impression that this type of behaviour has been redefined as something less than fraud. Those engaged in, for example, racism will likewise redefine the behaviour, both in private and to others, as something less than racism.

Techniques of neutralization allow for a common perception that equality programs are unjustified and deny the racist his or her entitlements. Other justifications include the notion that since everyone is doing it, it is acceptable, and the belief that if the behaviour is discovered, the consequences will not be serious.

\section{Can Techniques of Neutralization be Neutralized?}

Numbers are important even if they are not sufficient to change culture on their own. There are numerous ways that law schools ${ }^{26}$ law firms, ${ }^{27}$ and law societies ${ }^{28}$ can increase diversity. Smith provides a litany of things that law schools and law societies are doing and could do to increase diversity and these activities could eventually have an impact on techniques of neutralization.

Outside pressure can change the behaviour of law firms. A number of corporations in the United States are forcing lawyers to report the effect of their diversity efforts. Shell, for example, requires law firms it does business with to:

$[B]$ reak down their invoices by the race, ethnicity and gender of the billing lawyers, and tracks the statistics to ensure that women and minorities are not simply relegated to junior work. Once a year, Shell sends out reports showing how each firm compares relative to other Shell outside counsel, and providing bar graphs of hours billed and fees generated by female partners, female associates, minority partners and minority associates. Firms that consistently fall short of their peers face consequences. ${ }^{29}$

techniques of neutralization, their explanations as to why rules would not be effective are tangentially relevant as they offer some rationalizations and justifications for discrimination: see Joan Brockman, "The Use of Self-Regulation to Curb Discrimination and Sexual Harassment in the Legal Profession" (1997) 35 Osgoode Hall L.J. 209 at 224-26; Brockman, "Fraud," supra note 23.

26 For a call for an equity culture in law schools, see Emily Carasco, "Reflections on Employment Equity (the Hiring Component) and Law Schools in Ontario" in Sheehy \& McIntyre, supra note 3 at 97. See also Sanda Rodgers, "Educating for Equality: The Meaning of Feminist Administration for Legal Education in Canada" in Sheehy \& McIntyre, ibid. at 149; Hilary Sommerlad, "Becoming' a Lawyer: Gender and the Processes of Professional Identity Formation" in Sheehy \& McIntyre, ibid. at 159. For a heroic effort with respect to educating lawyers in large law firms, see Mary Jane Mossman, "Legal Education as a Strategy for Change in the Legal Profession" in Sheehy \& McIntyre, ibid. at 179; Mary Jane Mossman, "Engendering the Legal Profession: The Education Strategy" in Ulrike Schultz \& Gisela Shaw, eds., Women in the World's Legal Professions, Oñati International Series in Law and Society (Portland, Or.: Hart, 2003) 77.

28 See Rose Voyvodic, "Reimagining Legal Ethics After Touchstones for Change" in Sheehy \& McIntyre, ibid. at 345 .

29 Doug Jasinski, "Unless firms start paying attention to diversity, business may go downhill” The Lawyers Weekly (8 December 2006) (QL). 
At a recent session on "Sex, Age and Race Discrimination in Law Firms" at the International Bar Association Conference in Singapore, Mr. Ronald Zink, associate general counsel for Microsoft in Paris, reported that " 150 of some of the biggest corporations in the world [have] signed a 'call to action' to promote diversity for their legal departments and the law firms they hire." 30 He stated, "If nothing else, your clients will convince you that this is an important issue. If we had two equally qualified firms and one was diversified and one was not, then we would opt for the diversified firm." 31

If the behaviour of law schools and law firms are forced to change, their attitudes and culture may follow. It will, however, likely take a change in both numbers and culture before there is a significant change in what Smith refers to as the "unpardonable whiteness of the Canadian legal profession." 32 Law Review <http://www.iflr.com/?Page=9\&PUBid=263\&ISS=24208\&SID=696188> at para. 7. I would like to thank Richard Devlin for bringing this conference and paper to my attention. 